\title{
Trinta anos é muito tempo!
}

\author{
Thirty years is a long time!
}

Flávio Shansis, Paulo Oscar Teitelbaum*

* Editores da Rev Psiquiatr RS nos seus 30 anos.

Prezado leitor,

É com um sentimento especial que fazemos chegar até você este número da nossa Revista de Psiquiatria do Rio Grande do Sul, que marca seus 30 anos de publicação ininterrupta.

Trinta anos é muito tempo!

Ao olharmos para trás, para o agora distante ano de 1979, tomamos consciência do longo caminho percorrido.

Lembramos do interesse científico e associativo, da ousadia e determinação dos colegas que, ocupando as sucessivas diretorias da Associação de Psiquiatria do Rio Grande do Sul (APRS), decidiram criar e manter um canal de expressão e difusão do conhecimento psiquiátrico, enfrentando as muitas dificuldades e arcando com os significativos custos decorrentes.

Lembramos os muitos colegas que ocuparam a editoria da Revista e as dezenas de colegas que compuseram o seu Conselho Editorial em diferentes momentos, cada um dedicando significativa parcela de interesse, cuidado e o melhor de seu conhecimento para que a nossa Revista de Psiquiatria do Rio Grande do Sul pudesse se estabelecer e aperfeiçoar-se, conquistando a credibilidade e respeito científico de que hoje desfruta no cenário editorial psiquiátrico nacional.

Trinta anos é muito tempo!

No decorrer do tempo, o mundo mudou, a sociedade mudou, a psiquiatria mudou. E a Revista de Psiquiatria do Rio Grande do Sul também, em um esforço continuado para adaptar-se aos novos cenários.

Atualmente, seguindo os mais modernos padrões editoriais, possui um sistema de submissão de artigos inteiramente on-line, artigos avaliados de forma anônima por pareceristas altamente qualificados em suas respectivas subáreas de conhecimento e prioriza a difusão de conhecimento psiquiátrico a partir de artigos originais. Com isso, a Revista de Psiquiatria do Rio Grande do Sul atingiu parâmetros considerados de excelência para publicações do gênero, sendo procurada por autores das mais diversas latitudes.

Porém, ao lado da disposição da Revista de Psiquiatria do Rio Grande do Sul de evoluir e modificar-se, é motivo de satisfação e orgulho para todos nós sua capacidade de manter e valorizar as características mais marcantes do meio psiquiátrico que a idealizou e a viabilizou em seu crescimento ao longo desses 30 anos, entre as quais se destaca o respeito à pluralidade do pensamento e da prática psiquiátrica. Órgão oficial da APRS, a Revista de Psiquiatria do Rio Grande do Sul orgulha-se de ser seu reflexo no espírito de rigor científico aliado ao respeito aos diferentes vértices de abordagem do paciente.

Graças a tal espírito plural, que caracteriza a APRS, nosso leitor pode encontrar nas páginas da Revista de Psiquiatria do Rio Grande do Sul artigos originais que abordam temas tão diversos quanto, por exemplo, "Concentrações plasmáticas de paroxetina em pacientes adultos e idosos com depressão" ${ }^{\text {, }}$ ou "A relação entre os mecanismos de defesa e a qualidade da aliança terapêutica em psicoterapia de orientação analítica"2. No mundo editorial, poucos periódicos conseguem estimular e manter essa abordagem científica tão ampla e diversa. E disso nos orgulhamos muito.

Trinta anos é muito tempo!

Sendo a Revista de Psiquiatria do Rio Grande do Sul de hoje fruto do trabalho e das idéias de muitos colegas que nos antecederam, pareceu-nos oportuno, na presente edição comemorativa, compartilhar as experiências e a visão de alguns deles sobre diferentes momentos do passado.

Assim, convidamos você, leitor, para desfrutar conosco dos editoriais a convite de Cláudio L. Eizirik, o primeiro editor da Revista de Psiquiatria do Rio Grande do Sul, de Jair Escobar, o editor quando se completou a primeira década de vida, e de Gisele Gus Manfro e Edgar Diefenthaeler, a dupla de editores que estava à frente da Revista de Psiquiatria do Rio Grande do Sul por ocasião de seus 20 anos de existência.

Desejamos a todos uma agradável leitura.

Por agora e pelos próximos 30 anos!

\section{Referências}

1. Lima CAM, Baumann P, Eap CB. Concentrações plasmáticas de paroxetina em pacientes adultos e idosos com depressão. Rev Psiquiatr RS. 2008;30(1):13-8.

2. Gomes FG, Ceitlind LH, Hauck S, Terra L. A relação entre os mecanismos de defesa e a qualidade da aliança terapêutica em psicoterapia de orientação analítica. Rev Psiquiatr RS. 2008;30(2):109-14. 